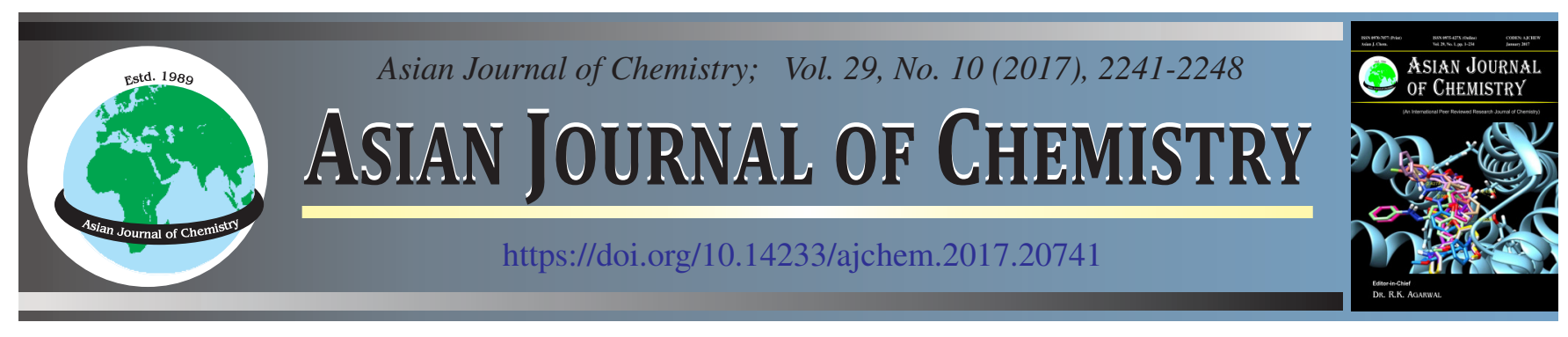

\title{
Ultraviolet Absorption Spectra, Solvent Effect and Non-Linear Optical Properties of Tetrahydroxy-1,4-quinone Hydrate by Hartee-Fock and Density Functional Theory
}

\author{
SARVENDRA KUMAR ${ }^{1, *}$, SURBHI $^{1}$ and M.K. YAdAV ${ }^{2}$
}

${ }^{1}$ Amity Institute of Applied Sciences, Amity University, Noida-201 313, India

${ }^{2}$ Department of Physics, D.N. Degree College, Meerut-250 002, India

*Corresponding author: E-mail: sarvendraricky @ rediffmail.com

Received: 29 April 2017;

Accepted: 15 June 2017;

Published online: 31 August 2017;

AJC-18528

\begin{abstract}
In present work, the ultraviolet absorption spectrum of tetrahydroxy-1,4-quinone hydrate (TH,1,4-QH) has been carried out experimentally (in water, methanol dimethyl sulfoxide, acetonitrile and chloroform) and theoretically in the range $3500-2300 \mathrm{~cm}^{-1}$ in the solution phase. Predicted electronic absorption spectra from time dependent density functional theory (TD-DFT) calculation have been analyzed and compared with the experimental UV-visible spectrum. The effects of hydroxy group substituent in benzoquinone ring have been analyzed. The electronic properties such as excitation energy, wavelength corresponding to absorption maxima $\left(\lambda_{\max }\right)$, oscillator strength (f), HOMO and LUMO energies are calculated by time-dependent density functional theory (TD-DFT) using HF/6-311++G(d,p) and B3LYP/6$311++\mathrm{G}(\mathrm{d}, \mathrm{p})$ as basis sets. The electric dipole moment $(\mu), \alpha$ (polarizability) and $\beta$ (first hyperpolarizability) have been computed to evaluate the NLO (non-linear optical) response of the investigated compound by Hartree-Fock (HF) and density functional theory (DFT) with B3LYP basis sets. Mulliken atomic charges of the atoms are calculated by DFT (B3LYP). In addition natural bond orbital (NBO) analysis has been done using TD-DFT with B3LYP/6-311++G(d,p) basis sets.
\end{abstract}

Keywords: Tetrahydroxy-1,4-quinone hydrate, Ultraviolet spectrum, Density Functional Theory, NLO properties, Hartee-Fock.

ᄂ _ - - - - - - - - - - - - - - - - - - - - - - - - - - -

\section{INTRODUCTION}

Electronic spectroscopy (UV) is concerned with electron transition between orbital of different energy, generally from the occupied orbital of highest energy to unoccupied orbital of lowest energy. The excitation is as a result of absorption of light, the quantum energy (E) of which is a function of frequency $(v)$. The excitation probability depends on the wave functions of both the excited and ground states of orbital concerned, however not all absorption of radiation by organic molecules result in electronic excitation. The rules about which a transition is allowed or forbidden, is a function of symmetry and multiplicity of the ground and excited state of the orbital concerned. The ultraviolet (electronics excitation) in a molecule is accompanied by change in rotational and vibrational quantum numbers; therefore absorption lines become a broad peak containing vibrational and rotational fine structures. However, the interaction of solute and solvent molecules blurred out the fine structures and a smooth curve is observed [1-4].

In extension of the earlier works on the ultraviolet absorption spectra of some substituted compounds of benzene [5-13], the present investigation is confined to the study of the UV absorption spectrum of tetrahydroxy-1,4-quinone hydrate (TH-
1,4-QH) (Fig. 1). There is no earlier report on the UV absorption spectrum and NBO of this molecule.

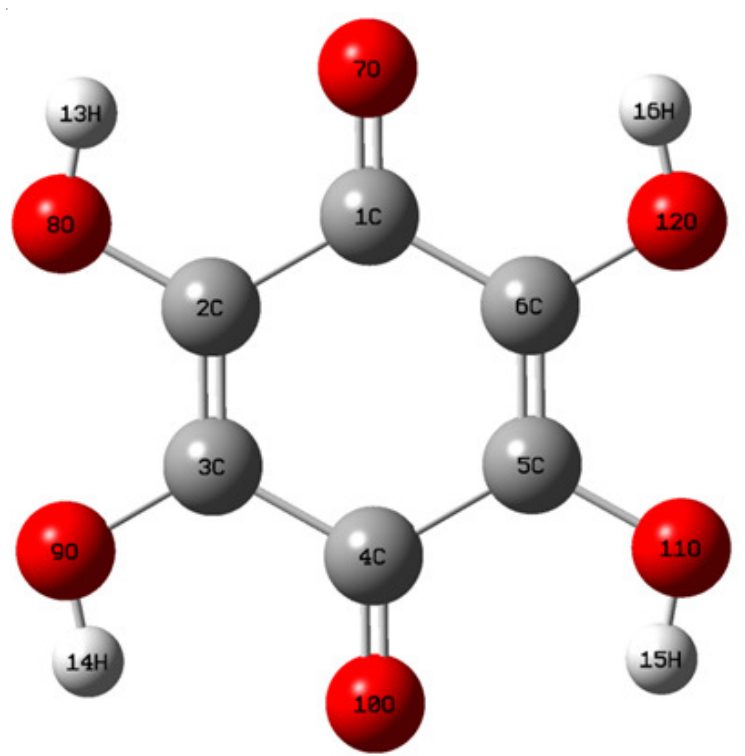

Fig. 1. Optimized geometric structure with atoms numbering of tetrahydroxy1,4-quinone hydrate 
As part of this investigation on spectroscopy, the detailed experimental studies on the electronic absorption spectra have been carried out. The object of present study is to investigate the of solvent's effect and substituent's on the absorption spectra of tetrahydroxy-1,4-quinone hydrate. The aim of present study is twofold namely:

i) To record the electronic absorption spectra for the substituted benzoquinone in different solvents and to study the effect of these solvents on the absorption spectra.

ii) To study the effect of substituent's on the absorption spectra.

\section{EXPERIMENTAL}

The compound tetrahydroxy-1,4-quinone hydrate (TH1,4-QH) in the solid form was purchased from Sigma Aldrich Chemical Pvt. Ltd., Germany with a stated purity of greater than $99 \%$ and was used as such without further purification. $\mathrm{UV} /$ visible spectra of TH-1,4-QH was recorded in solvents water, methanol, DMSO, acetonitrile and chloroform of different polarity (Fig. 2). The solvents were distilled several times to spectroquality grade, while the solute was used without further purification.

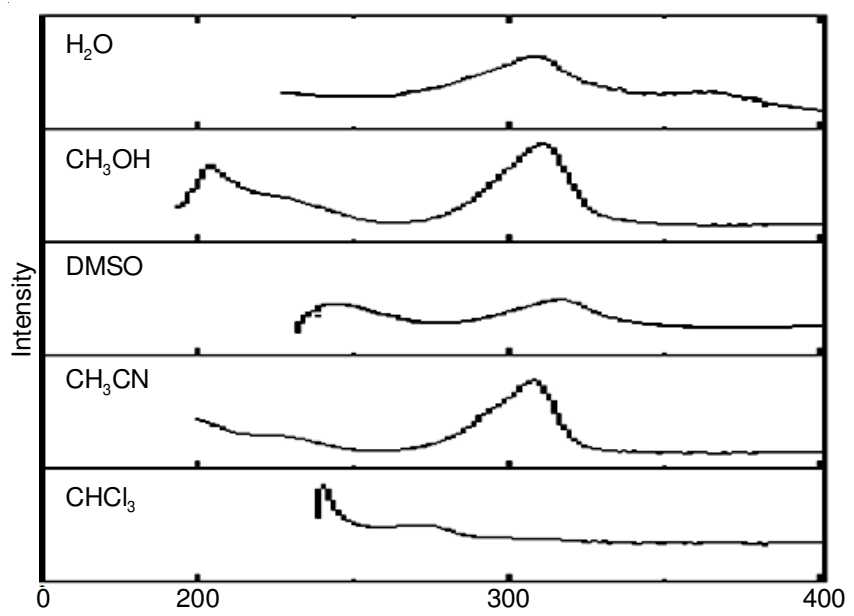

Fig. 2. UV-visible spectra of tetrahydroxy-1,4-quinone hydrate

Computational details: The computational work was done to determine the optimized geometry of TH-1,4-QH. The HF (Hartree Fock) and DFT (hybrid B3LYP: the Becke's threeparameter hybrid method with the Lee, Yang and Parr correlation functional) $[14,15]$ method was chosen for compound TH-1,4-QH. The entire calculations were performed by using the Gaussian 09 program package on a personal computer [16]. The electronic absorption spectra for optimized molecule calculated with the time dependent density functional theory (TD-DFT) at HF/6-311++G(d,p) and B3LYP/6-311++G(d,p) levels. The time-dependent HF and DFT (TD-HF and TDDFT) proved to be a powerful and effective computational tool for the study of ground and excited state properties by comparison to the available experimental data. Hence, we used TDB3LYP to obtain excitation energy, wavelengths $\left(\lambda_{\max }\right)$, oscillator strengths and compare with the experimental results of TH1,4-QH. The HOMO and LUMO energies are calculated by using HF and DFT methods with the same basis sets. The non- linear parameters (dipole moment, polarizability and first order hyperpolarizability), Mulliken atomic charges of the atoms are calculated by using HF and DFT methods with the same basis sets.

\section{RESULTS AND DISCUSSION}

\section{UV-visible absorption spectra}

Shift of $n-\pi^{*}$ and $\sigma-\sigma^{*}$ band of tetrahydroxy-1,4quinone hydrate in different solvents: Kasha [17], Sponer and Rush [18] have shown that the $n-\pi *$ system of benzoquinone appears at $245-280 \mathrm{~nm}$ and $\sigma-\sigma^{*}$ appears above than $280 \mathrm{~nm}$ in vapour phase. In present study, the spectra was studied in different solvents and in solid phase. The $n-\pi^{*}$ band has been observed at 268.99 and $265.06 \mathrm{~nm}$ in TH-1,4-QH with solvent chloroform and water respectively. It shows that band system is shifted towards shorter wavelength in TH-1,4-QH. The red shift observed at or above than $280 \mathrm{~nm}$ in TH-1,4-QH. The $\sigma-\sigma^{*}$ band has been observed at $310.98 \mathrm{~nm}, 307.90 \mathrm{~nm}$ and $316.52 \mathrm{~nm}$ in TH-1,4-QH with solvent methanol, acetonitrile and DMSO respectively.

Solvent effect: As suggested by Ram et al. [19] in benzoquinone the introduction of $-\mathrm{O}=$ group in place of $-\mathrm{CH}$ in benzene exhibit a blue shift in transition $2600 \AA$ band $\left(n-\pi^{*}\right)$. In the present study the near ultraviolet spectra of the molecule TH-1,4-QH was observed in different solvents viz. water, methanol, DMSO, acetonitrile and chloroform as shown in Fig. 3. The bands as higher absorption are taken to be $\sigma-\sigma^{*}$ band. The band system corresponds to $1_{\mathrm{Alg}} 1_{\mathrm{B} 2 \mathrm{u}} 2600 \AA$ ( $\left.\mathrm{n}-\pi^{*}\right)$ transition of benzene has been observed between 2650-2690 $\AA$ in TH-1,4-QH for different solvents. The shift of absorption band occurring upon a change from one solvent to another is due to the salvation energy of the solute in the ground and excited state and is equal to $\Delta \mathrm{v}=\mathrm{v}_{\mathrm{sol} 1}-\mathrm{v}_{\mathrm{sol} 2}$. According to Finar [20], polar solvents and those which can form hydrogen bands tend to interact electrostatically with various chromophores which changes the charge distribution in the molecule and results in increased delocalization. For $n-\pi^{*}$ system both ground and excited states are stabilized and absorption maxima moves towards longer wavelength as the polarity of the solvent increases.

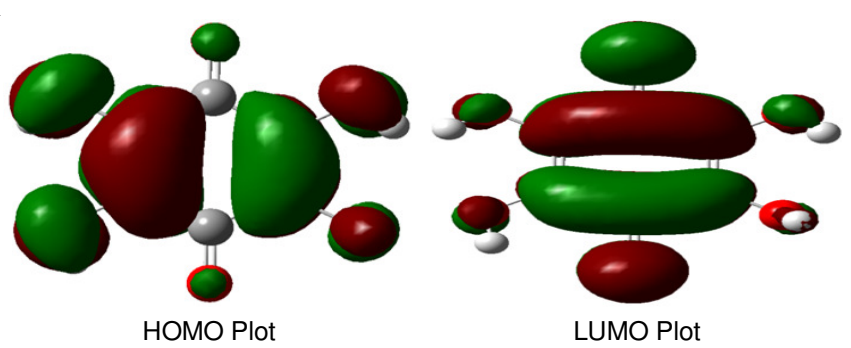

Fig. 3. Atomic orbital HOMO and LUMO compositions of the frontier molecular orbital for tetrahydroxy-1,4-quinone hydrate

The $n-\pi *$ transition shift towards shorter wavelength with the increase in the polarity of the solution because in this transition ground state is more stabilized than the excited state. In present study of TH-1,4-QH the $n-\pi^{*}$ system shift towards the shorter wavelength with the increase of the polarity of the solvent while going from DMSO to water (Table-1) with the 
TABLE-1

EFFECT OF SOLVENTS ON $n-\pi^{*}$ AND $\pi-\pi^{*}$ TRANSITION IN TETRAHYDROXY-1,4-QUINONE HYDRATE

\begin{tabular}{ccc}
\hline Solvent & Refractive index & $\lambda_{\max }$ for TH-1,4-QH \\
\hline Water & 1.3380 & 265.06 \\
Methanol & 1.3773 & 310.98 \\
Chloroform & 1.4458 & 268.99 \\
Acetonitrile & 1.3441 & 307.90 \\
DMSO & 1.4790 & 316.52 \\
\hline
\end{tabular}

exception in case of methanol. The wavelength also shifts towards shorter wavelength in case of $n$-hexane i.e. non polar solvent. From these, it seems that ground state is more stabilized than excited state in both $n-\pi *$ transitions.

In the spectra of monocyclic enzymes the absorption band due to transition of an electron from a lone pair orbital to a $\pi$ orbital of the ring is shifted towards red region by meta directing group. Stephensen [21] and Goodmen \& Harrall [22] have observed a blue shift in ortho halogenated pyridine and pointed out the substitution in ortho position exerted an influence through interaction with the non-bonding electron of the nitrogen. Therefore, as observed in present case the $n-\pi *$ system is observed blue shifted to meta directing TH-1,4-QH. In TH$1,4-\mathrm{QH}$ the blue shift from $n$-hexane to water is in the order of decreasing refractive index of the solvents (Table-2) which is in accordance with the work of Mataga and Kubota [23].

TABLE-2

ELECTRONIC ABSORPTION SPECTRA OF TETRAHYDROXY1,4-QUINONE HYDRATE [ABSORPTION WAVELENGTH $\lambda_{\max }$ $(\mathrm{nm})$, EXCITATION ENERGY (eV) AND OSCILLATOR STRENGTH (f)] USING TD-DFT WITH B3LYP/6-311++G(d,p) BASIS SETS

\begin{tabular}{cccccc}
\hline \multirow{2}{*}{ Solvents } & \multicolumn{2}{c}{$\mathrm{B}$ 3LYP/6-311++G(d,p)cis } & $\begin{array}{c}\text { Experimental } \\
\lambda_{\max }\end{array}$ & $\begin{array}{c}\text { Assign- } \\
\text { ments }\end{array}$ \\
\cline { 2 - 4 }$\lambda_{\max }$ & $\mathrm{E}$ & $\mathrm{F}$ & & $\sigma-\sigma^{*}$ \\
Chloroform & 289.73 & 4.2793 & 0.0038 & & \\
& 286.16 & 4.3327 & 0.0323 & 268.99 & $\sigma-\sigma^{*}$ \\
& 274.05 & 4.5241 & 0.0081 & & $\mathrm{n}-\pi^{*}$ \\
\hline \multirow{3}{*}{ Methanol } & 294.33 & 4.2124 & 0.1246 & & $\sigma-\sigma^{*}$ \\
& 282.36 & 4.3911 & 0.0149 & 310.98 & $\sigma-\sigma^{*}$ \\
& 273.78 & 4.5286 & 0.4407 & & $\mathrm{n}-\pi^{*}$ \\
\hline \multirow{3}{*}{ Water } & 294.47 & 4.2104 & 0.1283 & & $\sigma-\sigma^{*}$ \\
& 282.25 & 4.3928 & 0.0160 & 265.06 & $\sigma-\sigma^{*}$ \\
& 273.89 & 4.5268 & 0.5003 & & $\mathrm{n}-\pi^{*}$ \\
\hline \multirow{3}{*}{ Acetonitrile } & 294.47 & 4.2104 & 0.1283 & & $\sigma-\sigma^{*}$ \\
& 282.25 & 4.3928 & 0.0160 & 307.90 & $\sigma-\sigma^{*}$ \\
& 273.89 & 4.5268 & 0.5003 & & $\mathrm{n}-\pi^{*}$ \\
\hline \multirow{3}{*}{ DMSO } & 294.83 & 4.2052 & 0.1385 & & $\sigma-\sigma^{*}$ \\
& 281.97 & 4.3970 & 0.0199 & 316.52 & $\sigma-\sigma^{*}$ \\
& 274.26 & 4.5206 & 0.6730 & & $\mathrm{n}-\pi^{*}$ \\
\hline
\end{tabular}

On the basis of fully optimized ground-state structure, calculations have been performed to determine the low-lying excited states of TH-1,4-QH using B3LYP/6-311++G(d,p) basis sets. The calculated result involving the vertical excitation energies, oscillation strength (f) and wavelength $\left(\lambda_{\max }\right)$ are carried out as shown in Table-3 and compared with measured experimental wavelength listed in Table-2.

TH-1,4-QH the transitions for the transitions for B3LYP/ $6-311++\mathrm{G}(\mathrm{d}, \mathrm{p})$ basis set are observed at wavelengths at 274 , 286 and $289 \mathrm{~nm}$ in chloroform, at 273,282 and $294 \mathrm{~nm}$ in
TABLE-3

CALCULATED ENERGY VALUES (eV) OF TETRAHYDROXY-1,4QUINONE HYDRATE BY USING TD-DFT/B3LYP/6311++G(d,p)

\begin{tabular}{cc}
\hline Parameter & Values \\
\hline $\mathrm{E}_{\text {Hомо }}$ & -0.3813 \\
$\mathrm{E}_{\text {LUMO }}$ & -0.0117 \\
$\mathrm{E}_{\text {HOMO-1 }}$ & -0.4072 \\
$\mathrm{E}_{\text {LUMO-1 }}$ & -0.0433 \\
$\Delta \mathrm{E}$ & 0.3696 \\
$\partial \mathrm{E}$ & 0.3639 \\
$\mathrm{E}_{\text {Total }}$ (Hartree $)$ & -379.87 \\
\hline$\Delta \mathrm{E}=\mathrm{E}_{\text {LUMO }}-\mathrm{E}_{\text {Hомо }}, \partial \mathrm{E}=\mathrm{E}_{\text {LUMO+1 }}-\mathrm{E}_{\text {Hомо-1 }}$ &
\end{tabular}

methanol and at 273, 282 and $294 \mathrm{~nm}$ in water at 273, 282 and 294 in acetonitrile at 274, 281 and 294 in DMSO solvent. There are three values of wavelengths for each solvent. For each solvent the first wavelength corresponding to $n \rightarrow \pi^{*}$ and another two corresponding to $\sigma-\sigma^{*}$ transitions. The results obtained in B3LYP are nearer to experimental results.

HOMO-LUMO energy: The HOMO (highest occupied molecular orbital) energy characterizes the ability of electron giving, the LUMO (least unoccupied molecular orbital) characterizes the ability of electron accepting and the gap between HOMO and LUMO characterizes the molecular chemical stability. The energy gap between the HOMOs and LUMOs is a critical parameter in determining molecular electrical transport properties because it is a measure of electron conductivity. Both HOMO and LUMO are the main orbitals that take part in chemical stability. The energy values of LUMO and HOMO and their energy gap determines the kinetic stability, chemical reactivity and, optical polarizability and chemical hardnesssoftness of a molecule [24]. The molecule has a large energy gap is known as hard and having a small energy gap is known as soft molecule. The hard molecule is not more polarizable than the soft ones because they need big energy to excitation $[25,26]$. The decrease in the energy of HOMO and LUMO explains the ICT (intra molecular charge transfer) interaction taking place within the molecule which is highly responsible for the activity of the molecule. The HOMO-LUMO energy separation has served as a simple measure of kinetic stability. A molecule with a small or no HOMO-LUMO gap is a chemically reactive. Pearson showed that the HOMO-LUMO gap represents the chemical hardness of the molecule [27]. Another parameter that is calculated is electrophilicity index which measures the energy lowering of a ligand due to maximal electron flow between donor and acceptor [28]. The energies of HOMO, LUMO, HOMO -1 (second highest occupied molecular orbital) and $\mathrm{LUMO}_{+1}$ (second least unoccupied molecular orbital) and corresponding energy gap in different solvents for TH-1,4-QH are calculated with the TD-DFT method and same basis sets and presented in Table-3.

The complete equations for calculating ionization potential, electron affinity, chemical potential, global hardness, global softness, electronegativity and electrophilicity index are as follows (Table-4):

Ionization potential $(\mathrm{I})=-\mathrm{E}_{\mathrm{HOMO}}$

Electron affinity $(\mathrm{A})=-\mathrm{E}_{\mathrm{LUMO}}$

Chemical potential $(\mu)=\left(\mathrm{E}_{\text {LUMO }}+\mathrm{E}_{\text {Hомо }}\right) / 2$

Global hardness $(\eta)=\left(\mathrm{E}_{\text {LuмO }}-\mathrm{E}_{\mathrm{HOMO}}\right) / 2$ 
Global softness $(\mathrm{S})=1 / \eta$

Electronegativity $(\sigma)=-\mu$

Electrophilicity index $(\omega)=\mu^{2} / 2 \eta$

These values will be same for the solvents ethanol, methanol and water for each basis set since the values of $\mathrm{E}_{\text {Номо }}$ and $\mathrm{E}_{\mathrm{LUMO}}$ are same in all the solvents as shown in Table-4.

TABLE-4

COMPUTED IONIZATION POTENTIAL (I), ELECTRON

AFFINITY (A), CHEMICAL POTENTIAL $(\mu)$, GLOBAL HARDNESS ( $\eta$ ), GLOBAL SOFTNESS (S) IN eV ${ }^{-1}$, ELECTRONEGATIVITY $(\sigma)$ AND ELECTRO-PHILICITY INDEX ( $\omega)$ USING B3LYP/6-311++G(d,p) BASIS SETS

\begin{tabular}{lc}
\hline \multicolumn{1}{c}{ Parameters } & B3LYP/6311++G(d,p) $(\mathrm{eV})$ \\
\hline $\mathrm{E}_{\text {HOMO }}$ & -0.3813 \\
$\mathrm{E}_{\text {LUMO }}$ & -0.0117 \\
Ionization potential $(\mathrm{I})$ & 0.3813 \\
Electron affinity $(\mathrm{A})$ & 0.0117 \\
Chemical potential $(\mu)$ & -0.1962 \\
Global hardness $(\eta)$ & 0.1848 \\
Global softness $(\mathrm{S})$ & 5.4100 \\
Electronegativity $(\sigma)$ & 0.1962 \\
Electrophilicity index $(\omega)$ & 0.1041 \\
\hline
\end{tabular}

Mulliken charges: Mulliken charges estimates partial atomic charges calculated from the Mulliken population analysis $[29,30]$. Here HF/6-311++G(d,p) and B3LYP/6-311++G(d,p) basis sets used to calculate mulliken charges. The calculations are carried out by the methods of computational chemistry; particularly those based on the linear combination of atomic orbitals and are routinely used as variables in linear regression procedures. The mulliken charges of $\mathrm{TH}-1,4-\mathrm{QH}$ is shown in Fig. 4. The figure shows positive and negative charges of atoms of TH-1,4-QH.

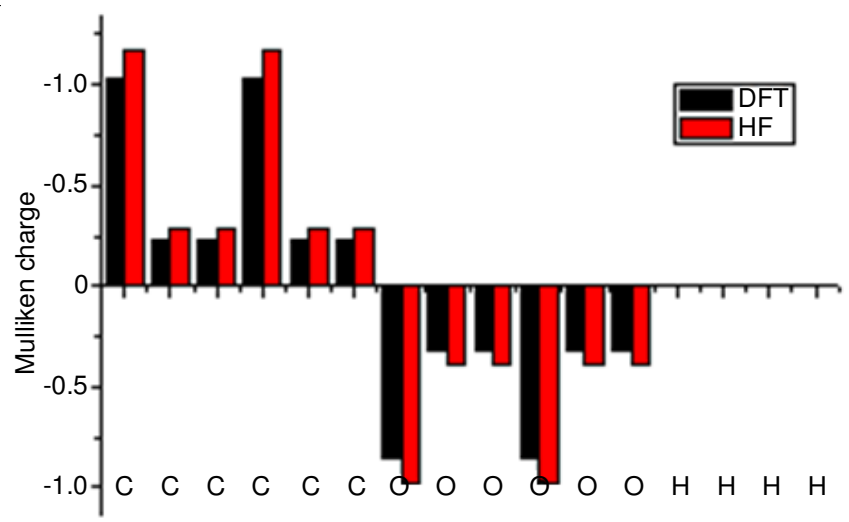

Fig. 4. Mulliken charges of TH-1,4-QH computed by HF/6-311++G(d,p) and B3LYP/6-31+G(d,p) basis sets [N-nitrogen, C-carbon, $\mathrm{H}$ hydrogen]

Non-linear optical (NLO) properties: The non-linear optical (NLO) effects arise from the interactions of electromagnetic fields in various media to produce new fields altered in frequency, amplitude, phase or other propagation characteristics from the incident fields. Non-linear optical is at the forefront of present research because of its importance in providing the key functions of optical modulation, frequency shifting, optical switching, optical logic and optical memory for promising technologies in the areas such as signal processing, telecommunications and optical interconnections [30-33].
TABLE-5

MULLIKEN CHARGES OF TETRAHYDROXY-1,4QUINONE HYDRATE COMPUTED BY HF/6-311++G(d,p) AND B3LYP/6-311+G(d,p) BASIS SETS

\begin{tabular}{cccc}
\hline S. No. & Atom & DFT & HF \\
\hline 1 & C & 1.025978 & 1.174681 \\
2 & C & 0.228656 & 0.292202 \\
3 & C & 0.228656 & 0.292202 \\
4 & C & 1.025978 & 1.174681 \\
5 & C & 0.228656 & 0.292202 \\
6 & C & 0.228656 & 0.292202 \\
7 & O & -0.853804 & -0.987257 \\
8 & O & -0.314742 & -0.385914 \\
9 & O & -0.314742 & -0.385914 \\
10 & O & -0.853804 & -0.987257 \\
11 & O & -0.314742 & -0.385914 \\
12 & O & -0.314742 & -0.385914 \\
13 & H & 0.000000 & 0.000000 \\
14 & H & 0.000000 & 0.000000 \\
15 & H & 0.000000 & 0.000000 \\
16 & H & 0.000000 & 0.000000 \\
\hline
\end{tabular}

The dipole moment $(\mu)$, polarizability $(\alpha)$ and second-order polarizability or the first hyperpolarizability $(\beta)$, are calculated using DFT with 6-31+G(d,p) and 6-311++G (d,p) basis sets on the basis of the finite-field approach. The complete equations for calculating the magnitude of total static dipole moment $\mu$, the mean polarizability $\langle\alpha\rangle$, the anisotropy of the polarizability $\Delta \alpha$ and the mean first hyperpolarizability $\beta_{\text {total }}$, using the $\mathrm{x}, \mathrm{y}$, $\mathrm{z}$ components from Gaussian $09 \mathrm{~W}$ output is as follows:

$$
\text { Dipole moment } \mu=\sqrt{\mu_{\mathrm{x}}^{2}+\mu_{\mathrm{y}}^{2}+\mu_{\mathrm{z}}^{2}}
$$

The mean polarizability and anisotropy of polarizability respectively are defined by

$$
\langle\alpha\rangle=\frac{1}{3}\left(\alpha_{\mathrm{xx}}+\alpha_{\mathrm{yy}}+\alpha_{\mathrm{zz}}\right)
$$

$\Delta \alpha=\frac{1}{\sqrt{2}}\left[\left(\alpha_{x x}-\alpha_{y y}\right)^{2}+\left(\alpha_{y y}-\alpha_{z z}\right)^{2}+\left(\alpha_{z z}-\alpha_{x x}\right)^{2}+6\left(\alpha_{x z}^{2}+\alpha_{x y}^{2}+\alpha_{y z}^{2}\right)\right]^{\frac{1}{2}}$

the mean first-order hyperpolarizability $\beta_{\text {Total }}$ is defined as:

$$
\beta_{\text {Total }}=\left(\beta_{\mathrm{x}}^{2}+\beta_{\mathrm{y}}^{2}+\beta_{\mathrm{z}}^{2}\right)^{\frac{1}{2}}
$$

where $\beta_{\mathrm{x}}=\beta_{\mathrm{xxx}}+\beta_{\mathrm{xyy}}+\beta_{\mathrm{xzz}}, \beta_{\mathrm{y}}=\beta_{\mathrm{yyy}}+\beta_{\mathrm{xxy}}+\beta_{\mathrm{yzz}}, \beta_{\mathrm{z}}=\beta_{\mathrm{zzz}}+$ $\beta_{\mathrm{xxz}}+\beta_{\mathrm{yyz}}$

It has been already proved that the higher values of dipole moment, molecular polarizability and hyperpolarizability are important for more active NLO properties. The calculated value of dipole moment was found to be 0.7129Debye using B3LYP/ $6-311++G(d, p)$ for tetrahydroxy-1,4-quinone hydrate. The highest value of dipole moment is observed for component $\mu_{\mathrm{x}}$ for TH-1,4-QH at all levels of theory. The calculated values of dipole moment with all components are shown in Table-6. The polarizabilities and first hyperpolarizability are reported in atomic units (a.u), the calculated values have been converted in to electrostatic units (esu) $\left(\alpha\right.$ : 1 a.u $=0.1482 \times 10^{-24}$ esu, $\beta$ : 1 a.u $\left.=8.6393 \times 10^{-33} \mathrm{esu}\right)$ [26].

The mean polarizabilities $(\alpha)$ and anisotropy of polarizability $(\Delta \alpha)$ are also included in Table-6 (molecules are in the xy 
TABLE- 6

NON-LINEAR OPTICAL PARAMETERS (DIPOLE MOMENT, POLARIZABILITY AND FIRST ORDER HYPERPOLARIZABILITY) OF TETRAHYDROXY-1,4-QUINONE HYDRATE

\begin{tabular}{|c|c|c|c|}
\hline Parameters & Values & Parameters & Values \\
\hline \multicolumn{2}{|c|}{ Dipole moments (Debye) } & \multicolumn{2}{|c|}{ Hyperpolarizability (a.u) } \\
\hline$\mu_{\mathrm{x}}$ & 0.0015 & $\beta_{\mathrm{xxx}}$ & 0.0134 \\
\hline$\mu_{\mathrm{y}}$ & -0.7104 & $\beta_{\mathrm{xxy}}$ & -2.0508 \\
\hline$\mu_{\mathrm{z}}$ & -0.0601 & $\beta_{\mathrm{xyy}}$ & -0.0135 \\
\hline$\mu_{\text {Total }}$ & 0.7129 & $\beta_{\mathrm{yyy}}$ & -5.6205 \\
\hline$\alpha_{x x}$ & -78.5673 & $\beta_{\mathrm{xxz}}$ & -0.1667 \\
\hline$\alpha_{\mathrm{xy}}$ & -0.1892 & $\beta_{\mathrm{xyz}}$ & 0.0421 \\
\hline$\alpha_{y y}$ & -63.7181 & $\beta_{\mathrm{yyz}}$ & -0.4983 \\
\hline$\alpha_{x z}$ & 0.2964 & $\beta_{\mathrm{xzz}}$ & 0.0080 \\
\hline$\alpha_{y z}$ & 0.4358 & $\beta_{\mathrm{yzz}}$ & -0.5324 \\
\hline$\alpha_{z z}$ & -67.0579 & $\beta_{z z z}$ & -0.1276 \\
\hline \multicolumn{2}{|c|}{ Polarizability (a.u) } & $\beta_{\text {Total }}$ & 8.242 (a.u) \\
\hline$\alpha$ & $\begin{array}{c}-69.955(\mathrm{a} . \mathrm{u})= \\
-10.3367 \times 10^{-24}(\mathrm{esu})\end{array}$ & $\beta_{\text {Total }}$ & $\begin{array}{c}71.205 \times \\
10^{-33}(\mathrm{esu})\end{array}$ \\
\hline$\Delta \alpha$ & $\begin{array}{c}258.802(\mathrm{a} . \mathrm{u})= \\
38.354 \times 10^{-24}(\mathrm{esu})\end{array}$ & & \\
\hline
\end{tabular}

plane). It is observed that the B3LYP/6-311++G(d,p) level of theory leads to higher polarizability in comparison to other method. The calculated values of polarizability is- $10.367 \times 10^{-24}$ esu using B3LYP/6-311++G(d,p). Additionally, the anisotropy of the polarizability $(\alpha)$ has been determined using ab initio and DFT methods. The calculated values is $38.354 \times 10^{-24}$ esu at B3LYP level for TH-1,4-QH. The first static hyperpolarizability calculated values are presented in Table- 6 . The values of $\beta_{\text {total }}$ is $71.205 \times$ $10^{-33}$ esu at B3LYP/6-311++G(d,p). The large value of hyperpolarizability calculated by the HF and B3LYP methods show that the studied compound is a good NLO material. The theoretical calculation of hyperpolarizability components is very useful as this clearly indicates the direction of charge delocalization [34].

NBO analysis: The natural population analysis performed on the electronic structure of title compound clearly describes the distribution of electrons in various sub-shells of their atomic orbitals. The accumulation of charges on the individual atom and accumulation of electrons in the core, valance and Rydberg sub-shells of tetrahydroxy,1-4-quinone hydrate are presented in Table-7. The most electronegative atoms like $\mathrm{O}_{8}, \mathrm{O}_{9}, \mathrm{O}_{11}$, $\mathrm{O}_{12}$, each have charges -0.65277 and $\mathrm{O}_{7}, \mathrm{O}_{10}$ both have the same charges-0.56287. The most electropositive atoms are $\mathrm{H}_{13}$, $\mathrm{H}_{14}, \mathrm{H}_{15}, \mathrm{H}_{16}$, with same charge 0.48987 and $\mathrm{C}_{1}, \mathrm{H}_{46}$, with same charge 0.45455 . From the point of view of electrostatic, electropositive atoms have a tendency to accept an electron, whereas the electronegative atoms have a tendency to donate an electron. Further, natural population analysis showed that 88 electrons in the title compound are distributed on the sub-shells as follows:

Core: 23.99130 (99.9637\% of 24)

Valence: 63.77933 (99.6552\% of 64)

Rydberg: 0.22937 (0.2606 \% of 88)

The occupancies and energies of lone pair molecular orbitals (LP) and anti-bonding (BD*) molecular orbitals of the Tetrahydroxy-1,4-quinone hydrate are predicted at B3LYP/ $6-311++G(d, p)$ level of theory and is presented in Table- 8 . The variations in occupancies and energies of the title molecule directly give the evidence for the delocalization of charge upon substitution and this leads to the variation of bond lengths.
TABLE-7

ACCUMULATION OF NATURAL CHARGE POPULATION OF ELECTRON IN CORE, VALENCE AND RYDBERG ORBITALS OF TETRAHYDROXY-1,4-QUINONE HYDRATE

\begin{tabular}{cccccc}
\hline \multirow{2}{*}{ Atom } & \multirow{2}{*}{ Charge } & \multicolumn{3}{c}{ Natural population } & \multirow{2}{*}{ Total } \\
\cline { 3 - 5 } & & Core & Valence & Rydberg & \\
\hline $\mathrm{C}_{1}$ & 0.45455 & 1.99923 & 3.50769 & 0.03852 & 5.54545 \\
$\mathrm{C}_{2}$ & 0.21706 & 1.99857 & 3.75903 & 0.02535 & 5.78294 \\
$\mathrm{C}_{3}$ & 0.21706 & 1.99857 & 3.75903 & 0.02535 & 5.78294 \\
$\mathrm{C}_{4}$ & 0.45455 & 1.99923 & 3.50769 & 0.03852 & 5.54545 \\
$\mathrm{C}_{5}$ & 0.21706 & 1.99857 & 3.75903 & 0.02535 & 5.78294 \\
$\mathrm{C}_{6}$ & 0.21706 & 1.99857 & 3.75903 & 0.02535 & 5.78294 \\
$\mathrm{O}_{7}$ & -0.56287 & 1.99979 & 6.54592 & 0.01716 & 8.56287 \\
$\mathrm{O}_{8}$ & -0.65277 & 1.99977 & 6.64063 & 0.01237 & 8.65277 \\
$\mathrm{O}_{9}$ & -0.65277 & 1.99977 & 6.64063 & 0.01237 & 8.65277 \\
$\mathrm{O}_{10}$ & -0.56287 & 1.99979 & 6.54592 & 001716 & 8.56287 \\
$\mathrm{O}_{11}$ & -0.65277 & 1.99977 & 6.64063 & 0.01237 & 8.65277 \\
$\mathrm{O}_{12}$ & -0.65277 & 1.99977 & 6.64063 & 0.01237 & 8.65277 \\
$\mathrm{H}_{13}$ & 0.48987 & 0 & 0.50526 & 0.00487 & 0.51013 \\
$\mathrm{H}_{14}$ & 0.48987 & 0 & 0.50526 & 0.00487 & 0.51013 \\
$\mathrm{H}_{15}$ & 0.48987 & 0 & 0.50526 & 0.00487 & 0.51013 \\
$\mathrm{H}_{16}$ & 0.48987 & 0 & 0.50526 & 0.00487 & 0.51013 \\
\hline Core: $23.99141(99.9642 \%$ of 24$)$ \\
Valence: 63.72687 (99.5732\% of 64) & & \\
Natural Minimal Basis: $87.71829(99.6799 \%$ of 88$)$ & \\
Natural Rydberg Basis: $0.28171(0.3201 \%$ of 88$)$ &
\end{tabular}

TABLE-8 SECOND ORDER PERTURBATION THEORY ANALYSIS OF FOCK MATRIX IN NBO BASIS OF TETRAHYDROXY-1,4-QUINONE HYDRATE

\begin{tabular}{|c|c|c|c|c|}
\hline $\begin{array}{c}\text { Donor } \\
\text { NBO }\end{array}$ & $\begin{array}{c}\text { Acceptor } \\
\text { NBO }\end{array}$ & $E(2)$ & $E_{j}-E_{i}$ & $F(i, j)$ \\
\hline \multirow[t]{5}{*}{$\mathrm{C}_{1}-\mathrm{C}_{2}$} & $\mathrm{C}_{1}-\mathrm{C}_{6}$ & 0.53 & 1.12 & 0.022 \\
\hline & $\mathrm{C}_{1}-\mathrm{O}_{7}$ & 0.83 & 1.25 & 0.029 \\
\hline & $\mathrm{C}_{2}-\mathrm{C}_{3}$ & 2.88 & 1.30 & 0.055 \\
\hline & $\mathrm{C}_{3}-\mathrm{O}_{9}$ & 4.98 & 1.07 & 0.065 \\
\hline & $\mathrm{C}_{6}-\mathrm{O}_{12}$ & 1.93 & 1.07 & 0.041 \\
\hline \multirow[t]{5}{*}{$\mathrm{C}_{1}-\mathrm{C}_{6}$} & $\mathrm{C}_{1}-\mathrm{C}_{2}$ & 0.53 & 1.12 & 0.022 \\
\hline & $\mathrm{C}_{1}-\mathrm{O}_{7}$ & 0.83 & 1.25 & 0.029 \\
\hline & $\mathrm{C}_{2}-\mathrm{O}_{8}$ & 1.93 & 1.07 & 0.041 \\
\hline & $\mathrm{C}_{5}-\mathrm{C}_{6}$ & 2.88 & 1.30 & 0.055 \\
\hline & $\mathrm{C}_{5}-\mathrm{O}_{11}$ & 4.98 & 1.07 & 0.065 \\
\hline \multirow[t]{6}{*}{$\mathrm{C}_{1}-\mathrm{O}_{7}$} & $\mathrm{C}_{1}-\mathrm{C}_{2}$ & 0.98 & 1.51 & 0.035 \\
\hline & $\mathrm{C}_{1}-\mathrm{C}_{6}$ & 0.98 & 1.51 & 0.035 \\
\hline & $\mathrm{C}_{2}-\mathrm{C}_{3}$ & 0.76 & 1.69 & 0.032 \\
\hline & $\mathrm{C}_{5}-\mathrm{C}_{6}$ & 0.76 & 1.69 & 0.032 \\
\hline & $\mathrm{C}_{2}-\mathrm{C}_{3}$ & 5.21 & 0.42 & 0.045 \\
\hline & $\mathrm{C}_{5}-\mathrm{C}_{6}$ & 5.21 & 0.42 & 0.046 \\
\hline \multirow[t]{10}{*}{$\mathrm{C}_{2}-\mathrm{C}_{3}$} & $\mathrm{C}_{1}-\mathrm{C}_{2}$ & 1.92 & 1.19 & 0.043 \\
\hline & $\mathrm{C}_{1}-\mathrm{O}_{7}$ & 1.52 & 1.32 & 0.040 \\
\hline & $\mathrm{C}_{2}-\mathrm{O}_{8}$ & 1.59 & 1.14 & 0.038 \\
\hline & $\mathrm{C}_{3}-\mathrm{C}_{4}$ & 1.92 & 1.19 & 0.043 \\
\hline & $\mathrm{C}_{3}-\mathrm{O}_{9}$ & 1.59 & 1.14 & 0.038 \\
\hline & $\mathrm{C}_{4}-\mathrm{O}_{10}$ & 1.52 & 1.32 & 0.040 \\
\hline & $\mathrm{O}_{8}-\mathrm{H}_{13}$ & 1.38 & 1.17 & 0.036 \\
\hline & $\mathrm{O}_{9}-\mathrm{H}_{14}$ & 1.38 & 1.17 & 0.036 \\
\hline & $\mathrm{C}_{1}-\mathrm{O}_{7}$ & 21.34 & 0.28 & 0.070 \\
\hline & $\mathrm{C}_{4}-\mathrm{O}_{10}$ & 21.34 & 0.28 & 0.070 \\
\hline \multirow[t]{3}{*}{$\mathrm{C}_{2}-\mathrm{O}_{8}$} & $\mathrm{C}_{1}-\mathrm{C}_{6}$ & 1.04 & 1.36 & 0.034 \\
\hline & $\mathrm{C}_{2}-\mathrm{C}_{3}$ & 1.56 & 1.54 & 0.044 \\
\hline & $\mathrm{C}_{3}-\mathrm{C}_{4}$ & 1.49 & 1.36 & 0.041 \\
\hline \multirow[t]{5}{*}{$\mathrm{C}_{3}-\mathrm{C}_{4}$} & $\mathrm{C}_{2}-\mathrm{C}_{3}$ & 2.88 & 1.30 & 0.055 \\
\hline & $\mathrm{C}_{2}-\mathrm{O}_{8}$ & 4.98 & 1.07 & 0.065 \\
\hline & $\mathrm{C}_{4}-\mathrm{C}_{5}$ & 0.53 & 1.12 & 0.022 \\
\hline & $\mathrm{C}_{4}-\mathrm{O}_{10}$ & 0.83 & 1.25 & 0.029 \\
\hline & $\mathrm{C}_{5}-\mathrm{O}_{11}$ & 1.93 & 1.07 & 0.041 \\
\hline
\end{tabular}




\begin{tabular}{|c|c|c|c|c|}
\hline \multirow[t]{3}{*}{$\mathrm{C}_{3}-\mathrm{O}_{9}$} & $\mathrm{C}_{1}-\mathrm{C}_{2}$ & 1.49 & 1.36 & 0.041 \\
\hline & $\mathrm{C}_{2}-\mathrm{C}_{3}$ & 1.56 & 1.54 & 0.044 \\
\hline & $\mathrm{C}_{4}-\mathrm{C}_{5}$ & 1.04 & 1.36 & 0.034 \\
\hline \multirow[t]{5}{*}{$\mathrm{C}_{4}-\mathrm{C}_{5}$} & $\mathrm{C}_{3}-\mathrm{C}_{4}$ & 0.53 & 1.12 & 0.022 \\
\hline & $\mathrm{C}_{3}-\mathrm{O}_{9}$ & 1.93 & 1.07 & 0.041 \\
\hline & $\mathrm{C}_{4}-\mathrm{O}_{10}$ & 0.83 & 1.25 & 0.029 \\
\hline & $\mathrm{C}_{5}-\mathrm{C}_{6}$ & 2.88 & 1.30 & 0.055 \\
\hline & $\mathrm{C}_{6}-\mathrm{O}_{12}$ & 4.98 & 1.07 & 0.065 \\
\hline \multirow[t]{5}{*}{$\mathrm{C}_{4}-\mathrm{O}_{10}$} & $\mathrm{C}_{2}-\mathrm{C}_{3}$ & 0.76 & 1.69 & 0.032 \\
\hline & $\mathrm{C}_{3}-\mathrm{C}_{4}$ & 0.98 & 1.51 & 0.035 \\
\hline & $\mathrm{C}_{4}-\mathrm{C}_{5}$ & 0.98 & 1.51 & 0.035 \\
\hline & $\mathrm{C}_{2}-\mathrm{C}_{3}$ & 5.21 & 0.42 & 0.045 \\
\hline & $\mathrm{C}_{5}-\mathrm{C}_{6}$ & 5.21 & 0.42 & 0.045 \\
\hline \multirow[t]{10}{*}{$\mathrm{C}_{5}-\mathrm{C}_{6}$} & $\mathrm{C}_{1}-\mathrm{C}_{6}$ & 1.92 & 1.19 & 0.043 \\
\hline & $\mathrm{C}_{1}-\mathrm{O}_{7}$ & 1.52 & 1.32 & 0.040 \\
\hline & $\mathrm{C}_{4}-\mathrm{C}_{5}$ & 1.92 & 1.19 & 0.043 \\
\hline & $\mathrm{C}_{4}-\mathrm{O}_{10}$ & 1.52 & 1.32 & 0.040 \\
\hline & $\mathrm{C}_{5}-\mathrm{O}_{11}$ & 1.59 & 1.14 & 0.038 \\
\hline & $\mathrm{C}_{6}-\mathrm{O}_{12}$ & 1.59 & 1.14 & 0.038 \\
\hline & $\mathrm{O}_{11}-\mathrm{H}_{15}$ & 1.38 & 1.17 & 0.036 \\
\hline & $\mathrm{O}_{12}-\mathrm{H}_{16}$ & 1.38 & 1.17 & 0.036 \\
\hline & $\mathrm{C}_{1}-\mathrm{O}_{7}$ & 21.34 & 0.28 & 0.070 \\
\hline & $\mathrm{C}_{4}-\mathrm{O}_{10}$ & 21.34 & 0.28 & 0.070 \\
\hline \multirow[t]{3}{*}{$\mathrm{C}_{5}-\mathrm{O}_{11}$} & $\mathrm{C}_{1}-\mathrm{C}_{6}$ & 1.49 & 1.36 & 0.041 \\
\hline & $\mathrm{C}_{3}-\mathrm{C}_{4}$ & 1.04 & 1.36 & 0.034 \\
\hline & $\mathrm{C}_{5}-\mathrm{C}_{6}$ & 1.56 & 1.54 & 0.044 \\
\hline \multirow[t]{3}{*}{$\mathrm{C}_{6}-\mathrm{O}_{12}$} & $\mathrm{C}_{1}-\mathrm{C}_{2}$ & 1.04 & 1.36 & 0.034 \\
\hline & $\mathrm{C}_{4}-\mathrm{C}_{5}$ & 1.49 & 1.36 & 0.041 \\
\hline & $\mathrm{C}_{5}-\mathrm{C}_{6}$ & 1.56 & 1.54 & 0.044 \\
\hline \multirow[t]{2}{*}{$\mathrm{O}_{8}-\mathrm{H}_{13}$} & $\mathrm{C}_{1}-\mathrm{C}_{2}$ & 0.82 & 1.16 & 0.028 \\
\hline & $\mathrm{C}_{2}-\mathrm{C}_{3}$ & 4.77 & 1.34 & 0.072 \\
\hline \multirow[t]{2}{*}{$\mathrm{O}_{9}-\mathrm{H}_{14}$} & $\mathrm{C}_{2}-\mathrm{C}_{3}$ & 4.77 & 1.34 & 0.072 \\
\hline & $\mathrm{C}_{3}-\mathrm{C}_{4}$ & 0.82 & 1.16 & 0.028 \\
\hline \multirow[t]{2}{*}{$\mathrm{O}_{11}-\mathrm{H}_{15}$} & $\mathrm{C}_{4}-\mathrm{C}_{5}$ & 0.82 & 1.16 & 0.028 \\
\hline & $\mathrm{C}_{5}-\mathrm{C}_{6}$ & 4.77 & 1.34 & 0.072 \\
\hline \multirow[t]{2}{*}{$\mathrm{O}_{12}-\mathrm{H}_{16}$} & $\mathrm{C}_{1}-\mathrm{C}_{6}$ & 0.82 & 1.16 & 0.028 \\
\hline & $\mathrm{C}_{5}-\mathrm{C}_{6}$ & 4.77 & 1.34 & 0.072 \\
\hline \multirow[t]{2}{*}{$\mathrm{LP}(1)-\mathrm{O}_{7}$} & $\mathrm{C}_{1}-\mathrm{C}_{2}$ & 1.08 & 1.15 & 0.032 \\
\hline & $\mathrm{C}_{1}-\mathrm{C}_{6}$ & 1.08 & 1.15 & 0.032 \\
\hline \multirow[t]{4}{*}{$\mathrm{LP}(2)-\mathrm{O}_{7}$} & $\mathrm{C}_{1}-\mathrm{C}_{2}$ & 17.28 & 0.72 & 0.101 \\
\hline & $\mathrm{C}_{1}-\mathrm{C}_{6}$ & 17.28 & 0.72 & 0.101 \\
\hline & $\mathrm{O}_{8}-\mathrm{H}_{13}$ & 2.02 & 0.70 & 0.035 \\
\hline & $\mathrm{O}_{12}-\mathrm{H}_{16}$ & 2.02 & 0.70 & 0.035 \\
\hline $\mathrm{LP}(1)-\mathrm{O}_{8}$ & $\mathrm{C}_{1}-\mathrm{C}_{2}$ & 5.77 & 1.03 & 0.070 \\
\hline $\mathrm{LP}(2)-\mathrm{O}_{8}$ & $\mathrm{C}_{2}-\mathrm{C}_{3}$ & 33.66 & 0.34 & 0.099 \\
\hline $\mathrm{LP}(1)-\mathrm{O}_{9}$ & $\mathrm{C}_{3}-\mathrm{C}_{4}$ & 5.77 & 1.03 & 0.070 \\
\hline $\mathrm{LP}(2)-\mathrm{O}_{9}$ & $\mathrm{C}_{2}-\mathrm{C}_{3}$ & 33.66 & 0.34 & 0.099 \\
\hline \multirow[t]{2}{*}{$\mathrm{LP}(1)-\mathrm{O}_{10}$} & $\mathrm{C}_{3}-\mathrm{C}_{4}$ & 1.08 & 1.15 & 0.032 \\
\hline & $\mathrm{C}_{4}-\mathrm{C}_{5}$ & 1.08 & 1.15 & 0.032 \\
\hline \multirow[t]{4}{*}{$\mathrm{LP}(2)-\mathrm{O}_{10}$} & $\mathrm{C}_{3}-\mathrm{C}_{4}$ & 17.28 & 0.72 & 0.101 \\
\hline & $\mathrm{C}_{4}-\mathrm{C}_{5}$ & 17.28 & 0.72 & 0.101 \\
\hline & $\mathrm{O}_{9}-\mathrm{H}_{14}$ & 2.02 & 0.70 & 0.035 \\
\hline & $\mathrm{O}_{11}-\mathrm{H}_{15}$ & 2.02 & 0.70 & 0.035 \\
\hline $\mathrm{LP}(1)-\mathrm{O}_{11}$ & $\mathrm{C}_{4}-\mathrm{C}_{5}$ & 5.77 & 1.03 & 0.070 \\
\hline $\mathrm{LP}(2)-\mathrm{O}_{11}$ & $\mathrm{C}_{5}-\mathrm{C}_{6}$ & 33.66 & 0.34 & 0.099 \\
\hline $\mathrm{LP}(1)-\mathrm{O}_{12}$ & $\mathrm{C}_{1}-\mathrm{C}_{6}$ & 5.77 & 1.03 & 0.070 \\
\hline $\mathrm{LP}(2)-\mathrm{O}_{12}$ & $\mathrm{C}_{5}-\mathrm{C}_{6}$ & 33.66 & 0.34 & 0.099 \\
\hline \multirow[t]{4}{*}{$\mathrm{C}_{1}-\mathrm{O}_{7}$} & $\mathrm{C}_{2}-\mathrm{C}_{3}$ & 57.15 & 0.03 & 0.074 \\
\hline & $\mathrm{C}_{5}-\mathrm{C}_{6}$ & 57.15 & 0.03 & 0.074 \\
\hline & $\mathrm{C}_{2}-\mathrm{C}_{3}$ & 57.15 & 0.03 & 0.074 \\
\hline & $\mathrm{C}_{5}-\mathrm{C}_{6}$ & 57.15 & 0.03 & 0.074 \\
\hline
\end{tabular}

The interactions result in a loss of occupancy from the localized NBO (nuclear bond orbital) of the idealized Lewis structure into an empty Non-Lewis orbital. NBO analysis of some pharmaceutical compounds has been performed by many spectroscopists [10-12]. The loan pair-anti-bonding interaction can be quantitatively described by second-order perturbation interaction [13-16] energy E(2). For each donor (i) and acceptor (j), the stabilization energy E(2) associated with the delocalization $\mathrm{i} \rightarrow \mathrm{j}$ is estimated as:

$$
\mathrm{E}(2)=\Delta \mathrm{E}_{\mathrm{ij}}=\mathrm{q}_{\mathrm{i}} \mathrm{F}(\mathrm{ij})^{2} / \varepsilon_{\mathrm{j}}-\varepsilon_{\mathrm{i}}
$$

where $\mathrm{q}_{\mathrm{i}}$ is the donor orbital occupancy, $\varepsilon_{\mathrm{i}}$ and $\varepsilon_{\mathrm{j}}$ are the diagonal elements and $F(i, j)$ is the off diagonal NBO Fock matrix element. The NBO analysis provides an efficient method for studying intermolecular and intramolecular bonding. It also provides a convenient basis for intermolecular charge transfer (ICT) or conjugative interactions in molecular system. Table- 8 presents the second order perturbation energies (often called as stabilizations energies or interaction energies) of most interaction NBO of tetrahydroxy-1,4-quinone hydrate. The second order perturbation energies correspond to the hyper conjugative interactions of the title compound such as $\mathrm{LP}(2) \mathrm{O}_{8} \rightarrow \mathrm{C}_{2}-\mathrm{C}_{3}, \mathrm{LP}(2) \mathrm{O}_{9} \rightarrow \mathrm{C}_{2}-\mathrm{C}_{3} \mathrm{LP}(2) \mathrm{O}_{12} \rightarrow \mathrm{C}_{5}-\mathrm{C}_{6}$ and $\mathrm{V}$ that are considerably very large with $33.66 \mathrm{~kJ} \mathrm{~mol}^{-1}$, respectively. These hyper conjugative interactions are most responsible ones for stability of title compound.

Electron contribution in $s$-type and $p$-type subshells: NBO analysis of title compound is performed to estimate the delocalization patterns of electron density (ED) from the principal occupied Lewis-type (bond or lone pair) orbitals to occupied non-Lewis (anti-bonding or Rydberg) orbitals. The list of occupancies and energies of most interacting NBOs along with their percentage of hybrid atomic orbitals is listed in Table-9.

TABLE-9

OCCUPANCIES AND ENERGIES OF ONE PAIR ORBITALS (LP) AND ANTI-BONDING (BD*) MOLECULAR ORBITALS OF TETRAHYDROXY-1,4-QUINONE HYDRATE

\begin{tabular}{|c|c|c|c|c|c|}
\hline Bond & Occupacy & Energy & Bond & Occupacy & Energy \\
\hline $\mathrm{C}_{1}-\mathrm{C}_{2}$ & 1.97598 & -0.72242 & $\mathrm{LP}(1)-\mathrm{O}_{10}$ & 1.98 & -075877 \\
\hline $\mathrm{C}_{1}-\mathrm{C}_{6}$ & 97598 & -0.72242 & $\mathrm{LP}(2)-\mathrm{O}_{10}$ & 1.88206 & -0.33020 \\
\hline $\mathrm{C}_{1}-\mathrm{O}_{7}$ & 1.99404 & -1.11244 & $\mathrm{LP}(1)-\mathrm{O}_{11}$ & 1.97521 & -0.64175 \\
\hline $\mathrm{C}_{1}-\mathrm{O}_{7}$ & 1.95775 & -0.42977 & $\mathrm{LP}(2)-\mathrm{O}_{11}$ & 1.84249 & -0.35268 \\
\hline $\mathrm{C}_{2}-\mathrm{C}_{3}$ & 1.97759 & -0.79565 & $\mathrm{LP}(1)-\mathrm{O}_{12}$ & 1.97521 & -0.64175 \\
\hline $\mathrm{C}_{2}-\mathrm{C}_{3}$ & 1.78698 & -0.32614 & $\mathrm{LP}(2)-\mathrm{O}_{12}$ & 1.84249 & -0.35268 \\
\hline $\mathrm{C}_{2}-\mathrm{O}_{8}$ & 1.99326 & -0.96565 & $\mathrm{C}_{1}-\mathrm{C}_{2}$ & 0.06639 & 0.39266 \\
\hline $\mathrm{C}_{3}-\mathrm{C}_{4}$ & 97598 & -0.72242 & $\mathrm{C}_{1}-\mathrm{C}_{6}$ & 639 & 0.39266 \\
\hline $\mathrm{C}_{3}-\mathrm{O}_{9}$ & 1.99326 & -0.96565 & $\mathrm{C}_{1}-\mathrm{O}_{7}$ & 0.00867 & 0.52743 \\
\hline $\mathrm{C}_{4}-\mathrm{C}_{5}$ & & 242 & $\mathrm{C}_{1}-\mathrm{O}_{7}$ & 358 & -0.04223 \\
\hline $\mathrm{C}_{4}-\mathrm{O}_{10}$ & & -1.1 & $\mathrm{C}_{2}-\mathrm{C}_{3}$ & & 0.57700 \\
\hline $\mathrm{C}_{4}-\mathrm{O}_{10}$ & 5775 & -0.4 & $\mathrm{C}_{2}-\mathrm{C}_{3}$ & & -0.01009 \\
\hline $\mathrm{C}_{5}-\mathrm{C}_{6}$ & 759 & 565 & $\mathrm{C}_{2}-\mathrm{O}_{8}$ & & 1425 \\
\hline $\mathrm{C}_{5}-\mathrm{C}_{6}$ & 698 & & $\mathrm{C}_{3}-\mathrm{C}_{4}$ & & 9266 \\
\hline $\mathrm{C}_{5}-\mathrm{O}_{11}$ & 326 & -0.9 & $\mathrm{C}_{3}-\mathrm{O}_{9}$ & & 1425 \\
\hline $\mathrm{C}_{6}-\mathrm{O}_{12}$ & 1.99326 & -0.96565 & $\mathrm{C}_{4}-\mathrm{C}_{5}$ & & 0.39266 \\
\hline $\mathrm{O}_{8}-\mathrm{H}_{13}$ & 1.98490 & -0.76349 & $\mathrm{C}_{4}-\mathrm{O}_{10}$ & 0.00867 & 0.52743 \\
\hline $\mathrm{O}_{9}-\mathrm{H}_{14}$ & 1.98490 & -0.76349 & $\mathrm{C}_{4}-\mathrm{O}_{10}$ & 0.25358 & -0.04223 \\
\hline $\mathrm{O}_{11}-\mathrm{H}_{15}$ & 1.98490 & -0.76349 & & 0.02761 & 0.57700 \\
\hline $\mathrm{O}_{12}-\mathrm{H}_{16}$ & 1.98490 & -0.76349 & ${ }_{5}-\mathrm{C}_{6}$ & 0.28762 & -0.01009 \\
\hline $\mathrm{LP}(1)-\mathrm{O}_{7}$ & 1.98140 & -0.75877 & ${ }_{5}-\mathrm{O}_{11}$ & 0.01754 & 0.34425 \\
\hline $\mathrm{LP}(2)-\mathrm{O}_{7}$ & & -0.33 & $\mathrm{C}_{6}-\mathrm{O}_{12}$ & & 0.34425 \\
\hline $\mathrm{LP}(1)-\mathrm{O}_{8}$ & 1.97521 & -0.64175 & $\mathrm{O}_{8}-\mathrm{H}_{13}$ & 0.01718 & 0.37179 \\
\hline $\mathrm{LP}(2)-\mathrm{O}_{8}$ & 1.84249 & -0.35268 & $\mathrm{O}_{9}-\mathrm{H}_{14}$ & 0.01718 & 0.37179 \\
\hline $\mathrm{LP}(1)-\mathrm{O}_{9}$ & 1.97521 & -0.64175 & $\mathrm{O}_{11}-\mathrm{H}_{15}$ & 0.01718 & 0.37179 \\
\hline $\mathrm{LP}(2)-\mathrm{O}_{9}$ & 1.84249 & -0.35268 & $\mathrm{O}_{12}-\mathrm{H}_{16}$ & 0.01718 & 0.37179 \\
\hline
\end{tabular}


The percentage of hybrid atomic orbitals of oxygen lone pair atom $\left(\mathrm{O}_{7}\right)$ and $\left(\mathrm{O}_{10}\right)$ shows that oxygen is partially contributed to both $s$-type and $p$-type subshells for LP(1), while oxygen is predominantly contributed to $p$-type subshell for $\mathrm{LP}(2)$. In contrast, all the anti-bonding orbitals of title compound shows that oxygen is partially contributed to both $s$-type and $p$-type subshell [35] as stated in Table-10.

TABLE-10

NATURAL ATOMIC ORBITAL OCCUPANCIES OF MOST INTERACTING (LONE PAIR AND ANTI-BONDING) NBO's OF TETRAHYDROXY-1,4-QUINONE HYDRATE

\begin{tabular}{|c|c|c|c|}
\hline Bond & Hybridization & $\mathrm{S}(\%)$ & $\mathrm{P}(\%)$ \\
\hline $\mathrm{C}_{1}-\mathrm{C}_{2}$ & $0.7045 \mathrm{sp}^{1.86}+0.7097 \mathrm{sp}^{2.05}$ & 49.63 & 50.37 \\
\hline $\mathrm{C}_{1}-\mathrm{C}_{6}$ & $0.7045 \mathrm{sp}^{1.86}+0.7097 \mathrm{sp}^{2.05}$ & 49.63 & 50.37 \\
\hline $\mathrm{C}_{1}-\mathrm{O}_{7}$ & $0.5943 \mathrm{sp}^{2.32}+0.8042 \mathrm{sp}^{1.47}$ & 35.32 & 64.64 \\
\hline $\mathrm{C}_{1}-\mathrm{O}_{7}$ & $0.5634 \mathrm{sp}^{1.0}+0.8262 \mathrm{sp}^{1.0}$ & 31.74 & 68.26 \\
\hline $\mathrm{C}_{1}-\mathrm{C}_{3}$ & $0.7071 \mathrm{sp}^{1.50}+0.7071 \mathrm{sp}^{1.00}$ & 50.00 & 50.00 \\
\hline $\mathrm{C}_{2}-\mathrm{C}_{3}$ & $0.7071 \mathrm{sp}^{1.00}+0.7071 \mathrm{sp}^{1.50}$ & 50.00 & 50.00 \\
\hline $\mathrm{C}_{1}-\mathrm{O}_{8}$ & $0.5862 \mathrm{sp}^{2.70}+0.8102 \mathrm{sp}^{1.99}$ & 34.36 & 65.64 \\
\hline $\mathrm{C}_{3}-\mathrm{C}_{4}$ & $0.7097 \mathrm{sp}^{2.05}+0.7045 \mathrm{sp}^{1.86}$ & 50.37 & 49.63 \\
\hline $\mathrm{C}_{3}-\mathrm{O}_{9}$ & $0.5862 \mathrm{sp}^{2.70}+0.8102 \mathrm{sp}^{1.99}$ & 34.36 & 65.64 \\
\hline $\mathrm{C}_{4}-\mathrm{C}_{5}$ & $0.7045 \mathrm{sp}^{1.86}+0.7097 \mathrm{sp}^{2.05}$ & 49.63 & 50.37 \\
\hline $\mathrm{C}_{4}-\mathrm{O}_{10}$ & $0.5943 \mathrm{sp}^{2.32}+0.8042 \mathrm{sp}^{1.47}$ & 35.32 & 64.68 \\
\hline $\mathrm{C}_{4}-\mathrm{O}_{10}$ & $0.5634 \mathrm{sp}^{1.00}+0.8262 \mathrm{sp}^{1.00}$ & 31.74 & 68.26 \\
\hline $\mathrm{C}_{5}-\mathrm{C}_{6}$ & $0.7071 \mathrm{sp}^{1.50}+0.7071 \mathrm{sp}^{1.50}$ & 50.00 & 50.00 \\
\hline $\mathrm{C}_{5}-\mathrm{C}_{6}$ & $0.7071 \mathrm{sp}^{1.00}+0.7071 \mathrm{sp}^{1.00}$ & 50.00 & 50.00 \\
\hline $\mathrm{C}_{5}-\mathrm{O}_{11}$ & $0.5862 \mathrm{sp}^{2.70}+0.8102 \mathrm{sp}^{1.99}$ & 34.36 & 65.64 \\
\hline $\mathrm{C}_{6}-\mathrm{O}_{12}$ & $0.5862 \mathrm{sp}^{2.70}+0.8102 \mathrm{sp}^{1.99}$ & 34.36 & 65.64 \\
\hline $\mathrm{O}_{8}-\mathrm{H}_{13}$ & $0.8677 \mathrm{sp}^{3.75}+0.4972 \mathrm{sp}^{0.00}$ & 75.28 & 24.72 \\
\hline $\mathrm{O}_{9}-\mathrm{H}_{14}$ & $0.8677 \mathrm{sp}^{3.75}+0.4972 \mathrm{sp}^{0.00}$ & 75.28 & 24.72 \\
\hline $\mathrm{O}_{11}-\mathrm{H}_{15}$ & $0.8677 \mathrm{sp}^{3.75}+0.4972 \mathrm{sp}^{0.00}$ & 75.28 & 24.72 \\
\hline $\mathrm{O}_{12}-\mathrm{H}_{16}$ & $0.8677 \mathrm{sp}^{3.75}+0.4972 \mathrm{sp}^{0.00}$ & 75.28 & 24.72 \\
\hline $\mathrm{LP}(1)-\mathrm{O}_{7}$ & $\mathrm{Sp}^{0.68}$ & & \\
\hline $\mathrm{LP}(2)-\mathrm{O}_{7}$ & $\mathrm{Sp}^{1.00}$ & & \\
\hline $\mathrm{LP}(1)-\mathrm{O}_{8}$ & $\mathrm{Sp}^{1.19}$ & & \\
\hline $\mathrm{LP}(2)-\mathrm{O}_{8}$ & $\mathrm{Sp}^{1.00}$ & & \\
\hline $\mathrm{LP}(1)-\mathrm{O}_{9}$ & $\mathrm{Sp}^{1.99}$ & & \\
\hline $\mathrm{LP}(2)-\mathrm{O}_{9}$ & $\mathrm{Sp}^{1.00}$ & & \\
\hline $\mathrm{LP}(1)-\mathrm{O}_{10}$ & $\mathrm{Sp}^{0.68}$ & & \\
\hline $\mathrm{LP}(2)-\mathrm{O}_{10}$ & $\mathrm{Sp}^{1.00}$ & & \\
\hline $\mathrm{LP}(1)-\mathrm{O}_{11}$ & $\mathrm{Sp}^{1.19}$ & & \\
\hline $\mathrm{LP}(2)-\mathrm{O}_{11}$ & $\mathrm{Sp}^{1.00}$ & & \\
\hline $\mathrm{LP}(1)-\mathrm{O}_{12}$ & $\mathrm{Sp}^{1.99}$ & & \\
\hline $\mathrm{LP}(2)-\mathrm{O}_{12}$ & $\mathrm{Sp}^{1.00}$ & & \\
\hline $\mathrm{C}_{1}-\mathrm{C}_{2}$ & $0.7097 \mathrm{sp}^{1.86}-0.7045 \mathrm{p}^{2.05}$ & 50.37 & 49.63 \\
\hline $\mathrm{C}_{1}-\mathrm{C}_{6}$ & $0.7097 \mathrm{sp}^{1.86}-0.7045 \mathrm{p}^{2.05}$ & 50.37 & 49.63 \\
\hline $\mathrm{C}_{1}-\mathrm{O}_{7}$ & $0.8042 \mathrm{sp}^{2.32}-0.5943 \mathrm{sp}^{1.47}$ & 64.68 & 35.32 \\
\hline $\mathrm{C}_{1}-\mathrm{O}_{7}$ & $0.8262 \mathrm{sp}^{1.00}-0.5634 \mathrm{sp}^{1.00}$ & 68.26 & 31.74 \\
\hline $\mathrm{C}_{2}-\mathrm{C}_{3}$ & $0.7071 \mathrm{sp}^{1.50} 0.7071 \mathrm{sp}^{1.50}$ & 50.00 & 50.00 \\
\hline $\mathrm{C}_{2}-\mathrm{C}_{3}$ & $0.7071 \mathrm{sp}^{1.00} 0.7071 \mathrm{sp}^{1.00}$ & 50.00 & 50.00 \\
\hline $\mathrm{C}_{2}-\mathrm{O}_{8}$ & $0.8102 \mathrm{sp}^{2.70}-0.5862 \mathrm{sp}^{1.99}$ & 65.64 & 34.36 \\
\hline $\mathrm{C}_{3}-\mathrm{C}_{4}$ & $0.7045 \mathrm{sp}^{2.05}-0.7097 \mathrm{sp}^{1.86}$ & 49.63 & 50.37 \\
\hline $\mathrm{C}_{3}-\mathrm{O}_{9}$ & $0.8102 \mathrm{sp}^{2.70}-0.5862 \mathrm{sp}^{1.99}$ & 65.64 & 34.36 \\
\hline $\mathrm{C}_{4}-\mathrm{C}_{5}$ & $0.7097 \mathrm{sp}^{1.86}-0.7045 \mathrm{p}^{2.05}$ & 50.37 & 49.63 \\
\hline $\mathrm{C}_{4}-\mathrm{O}_{10}$ & $0.8042 \mathrm{sp}^{2.32}-0.5943 \mathrm{sp}^{1.47}$ & 64.68 & 35.32 \\
\hline $\mathrm{C}_{4}-\mathrm{O}_{10}$ & $0.8262 \mathrm{sp}^{1.00}-0.5634 \mathrm{sp}^{1.00}$ & 68.26 & 31.74 \\
\hline $\mathrm{C}_{5}-\mathrm{C}_{6}$ & $0.7071 \mathrm{sp}^{1.50} 0.7071 \mathrm{sp}^{1.50}$ & 50.00 & 50.00 \\
\hline $\mathrm{C}_{5}-\mathrm{C}_{6}$ & $0.7071 \mathrm{sp}^{1.00} 0.7071 \mathrm{sp}^{1.00}$ & 50.00 & 50.00 \\
\hline $\mathrm{C}_{5}-\mathrm{O}_{11}$ & $0.8102 \mathrm{sp}^{2.70}-0.5862 \mathrm{sp}^{1.99}$ & 65.64 & 34.36 \\
\hline $\mathrm{C}_{6}-\mathrm{O}_{12}$ & $0.8102 \mathrm{sp}^{2.70}-0.5862 \mathrm{sp}^{1.99}$ & 65.64 & 34.36 \\
\hline $\mathrm{O}_{8}-\mathrm{H}_{13}$ & $0.4972 \mathrm{sp}^{3.75}-0.8677 \mathrm{sp}^{0.00}$ & 24.72 & 75.28 \\
\hline $\mathrm{O}_{9}-\mathrm{H}_{14}$ & $0.4972 \mathrm{sp}^{3.75}-0.8677 \mathrm{sp}^{0.00}$ & 24.72 & 75.28 \\
\hline $\mathrm{O}_{11}-\mathrm{H}_{15}$ & $0.4972 \mathrm{sp}^{3.75}-0.8677 \mathrm{sp}^{0.00}$ & 24.72 & 75.28 \\
\hline $\mathrm{O}_{12}-\mathrm{H}_{16}$ & $0.4972 \mathrm{sp}^{3.75}-0.8677 \mathrm{sp}^{0.00}$ & 24.72 & 75.28 \\
\hline
\end{tabular}

\section{Conclusion}

In the present work, an attempt has been made on the experimental and theoretical UV-visible spectral studies, HOMO-LUMO energies, Mulliken charges and NLO properties of industrially important tetrahydroxy-1,4-quinone hydrate. Equilibrium geometries, electronic parameters and thermodynamic parameters of tetrahydroxy-1,4-quinone hydrate have been analyzed at HF and DFT/B3LYP using 6-311++G(d,p) basis set. The Time dependent-DFT calculations on the molecule provided deep insight into their electronic structures and properties. In addition, the calculated UV-visible results functions are all in good agreement with the experimental data. The lowering of HOMO-LUMO band gap supports bioactive property of the molecule. The predicted NLO properties show that the title compound is a good candidate as non-linear optical material. The calculated first hyperpolarizability is comparable with the reported values of similar derivatives and is an attractive object for future studies of non-linear optics.

\section{REFERENCES}

1. R.M. Silverstein, G.C. Bassler and T.C. Morrill, Spectrometric Identification of Organic Compounds, John Wiley, New York (2004).

2. P.S. Kalsi, Spectroscopy of Organic Compounds, New Age International, New Delhi, India (2005).

3. E.A. Braude, UV and Visible Light Absorption in Determination of Organic Structures by Physical Methods, Academic Press, New York (1955).

4. Y.R. Sharma, Elementary Organic Spectroscopy, Principle and Chemical Applications, S. Chand and Company Ltd., New Delhi (1998).

5. R.N. Medhi, R. Barman, K.C. Medhi and S.S. Jois, Spectrochim. Acta A Mol. Biomol. Spectrosc., 54, 623 (1998); https://doi.org/10.1016/S1386-1425(97)00250-3.

6. K.C. Medhi and R.N. Medhi, Spectrochim. Acta A Mol. Spectrosc., 49, 1024 (1993);

https://doi.org/10.1016/0584-8539(93)80225-Y.

7. K.C. Medhi and R.N. Medhi, Spectrochim. Acta A Mol. Spectrosc., 47, 1061 (1991); https://doi.org/10.1016/0584-8539(91)80036-I.

8. K.C. Medhi and R.N. Medhi, Spectrochim. Acta A Mol. Spectrosc., 46, 1333 (1990); https://doi.org/10.1016/0584-8539(90)80138-O

9. D. Shoba, S. Periandi, S. Boomadevi, S. Ramalingam and E. Fereyduni, Spectrochim. Acta A Mol. Biomol. Spectrosc., 118, 438 (2014); https://doi.org/10.1016/j.saa.2013.09.023.

10. M. Arivazhagan and D.A. Rexalin, Spectrochim. Acta A Mol. Biomol. Spectrosc., 107, 347 (2013); https://doi.org/10.1016/j.saa.2013.01.029.

11. R. Mathammal, N. Sudha, L.G. Prasad, N. Ganga and V. Krishnakumar, Spectrochim. Acta A Mol. Biomol. Spectrosc., 137, 740 (2015); https://doi.org/10.1016/j.saa.2014.08.099.

12. B.S. Yadav, R. Kumar, M.K. Singh and J. Teotia, Int. Trans. Appl. Sci., 1, 581 (2009).

13. J.T. Vinita, Seema and M.K.Yadav, Int. Trans. Appl. Sci., 6, 205 (2014).

14. A.D. Becke, J. Chem. Phys., 98, 5648 (1993); https://doi.org/10.1063/1.464913.

15. C. Lee, W. Yang and R.G. Parr, Phys. Rev. B, 37, 785 (1988); https://doi.org/10.1103/PhysRevB.37.785.

16. M.J. Frisch et al., Gaussian 09 program, Revision A.02, Gaussian, Inc., Wallingford CT, 2009.

17. M. Kasha, Discuss. Faraday Soc., 9, 14 (1950); https://doi.org/10.11039/DF9500900014.

18. J.H. Rush and H. Sponer, J. Chem. Phys., 20, 1847 (1952); https://doi.org/10.1063/1.1700327.

19. K. Ram, B.R. Pandey and R.S. Tripathi, J. Chim. Phys., 74, 1150 (1977); https://doi.org/10.1051/jcp/1977741150.

20. I.L. Finar, Organic Chemistry, Longmans, London, edn 5, vol. 2 (1975).

21. S. Stephenson, J. Chem. Phys., 22, 1077 (1954); https://doi.org/10.1063/1.1740268. 
22. L. Goodman and R.W. Harrell, J. Chem. Phys., 30, 1131 (1959); https://doi.org/10.1063/1.1730147.

23. N. Mataga and T. Kubota, Molecular Introductions and Electronic Spectra, Marcel Dekkar Inc., New York (1970).

24. J.L. Reed, J. Phys. Chem. A, 101, 7396 (1997); https://doi.org/10.1021/jp9711050.

25. C.W. Kwon, A. Poquet, S. Mornet, G. Campet, M.H. Delville, M. Treguer and J. Portier, Mater. Lett., 51, 402 (2001); https://doi.org/10.1016/S0167-577X(01)00328-7.

26. R. Kumar, S. Kumar and J. Teotia, J. Adv. Phys., 8, 2122 (2015).

27. R. Pearson, J. Chem. Sci., 117, 369 (2005); https://doi.org/10.1007/BF02708340.

28. R.G. Parr, L.V. Szentpaly and S. Liu, J. Am. Chem. Soc., 121, 1922 (1999); https://doi.org/10.1021/ja983494x.

29. R.S. Mulliken, J. Chem. Phys., 23, 1833 (1955); https://doi.org/10.1063/1.1740588.

30. I.G. Csizmadia, Theory and Practice of MO Calculations on Organic Molecules, Elsevier, Amsterdam (1976).
31. M.G. Papadopoulos, A.J. Sadlej, J. Sadley and J. Leszczynski, NonLinear Optical Properties of Matter, In: Challenges and Advances in Computational Chemistry and Physics, Springer, vol. 1 (2006).

32. D.S. Chemla, Rep. Prog. Phys., 43, 1191 (1980); https://doi.org/10.1088/0034-4885/43/10/001.

33. R. Rajendran, T.H. Freeda, U.L. Kalasekar and R.N. Peruma, Adv. Mater. Phys. Chem., 1, 39 (2011); https://doi.org/10.4236/ampc.2011.12007.

34. J. Teotia, S. Kumar, Surbhi, R. Kumar and M.K. Yadav, Asian J. Chem., 28, 2204 (2016); https://doi.org/10.14233/ajchem.2016.19928.

35. S. Kumar, Surbhi and M.K.Yadav, eds.: B.M.K. Prasad, K.K. Singh, N. Ruhil, K. Singh and R. O'Kennedy, UV-Vis Studies and Quantum Analysis of 2,3,5,6-Tetramethyl-1,4-benzoquinone using HF and DFT Method, In: Communication and Computing Systems, Proceeding of Taylor and Francis Group, CRC Press, Boca Raton, FL, pp. 713-719 (2017);

https://doi.org/10.1201/9781315364094-128.

